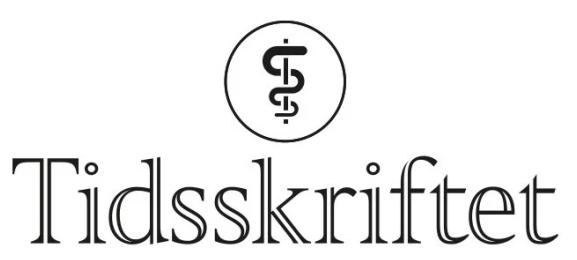

DEN NORSKE LEGEFORENING

\title{
Dødshjelp og moralske plikter
}

\author{
KOMMENTAR \\ EIVIND MELAND \\ eivind.meland@uib.no \\ Eivind Meland er professor emeritus. \\ Forfatteren har ikke oppgitt noen interessekonflikter.
}

Jeg takker Morten A. Horn og Siri Brelin for en saklig og opplysende kronikk om dødshjelp og assistert selvmord i Tidsskriftet (1). Konsekvensene av «moralsk glideflukt» med henvisning til opinionsmålinger beskriver de godt og veldokumentert. Jeg er stolt av å være medlem i en forening som ikke gir seg den liberale likegyldighet i vold med et nøytralt standpunkt til et så grunnleggende moralsk spørsmål. Det var filosofen Hans Skjervheim som i sin tid forklarte hvordan liberalitet kunne overdrives til likegyldighet og utvikles til en form for autoritær illiberalitet (2).

Det må vi beskytte oss mot, og derfor er det ett perspektiv jeg savner i kronikken: Vi har ikke bare forpliktelser overfor lidende individer som ikke aksepterer de lidelser som dødsprosessen kan innebære for noen. Vi har heller ikke bare forpliktelser overfor et flertall i et demokratisk samfunn. Vi har forpliktelser for samfunnet som helhet. Vi har forpliktelse for fremtiden og for «flokken vår», som Per Fugelli ville sagt det (3).

Retten til selvbestemt død kan nemlig føre til at andre føler plikt til ikke å være til byrde. Det representerer en grenseoverskridelse som undergraver vår plikt til omsorgsfullhet overfor de lidende, som har vansker med å akseptere at de ligger andre til last. Den hippokratiske ed om ikke å ta liv er et uttrykk for at moralen ikke bare kan hensynta individer, men også må være basert på kollektive hensyn.

Jeg spør meg selv om moderne medisin er medskyldig til at dødshjelp aksepteres. Vi håndterer ikke menneskelig lidelse på en adekvat måte. I stedet for å anerkjenne at lidelse er et grunnvilkår i livene våre og en kilde til personlig vekst, forfører vi mange inn i illusjoner om et symptomfritt liv.

Aspirasjonen om å fjerne den menneskelige lidelse som knytter seg til døden, er en naturlig følge av denne forføreriske tenkningen og praksisen knyttet til moderne menneskers møte med lidelse. Det er all mulig grunn til å beskytte fellesskapet mot et offentlig sanksjonert brudd på budet om ikke å ta liv. Vi kan i stedet arbeide for at helsevesenet og velferdsstaten tilegner seg evne til med vennlighet å akseptere og romme menneskelig lidelse i alle faser av det menneskelige liv. 
1. Horn MA, Brelin S. Legeforeningen bør fortsatt si nei til dødshjelp. Tidsskr Nor Legeforen $2021 ; 141$. doi: 10.4045/tidsskr.21.0658. [PubMed][CrossRef]

2. Skjervheim H. Det liberale dilemma og andre essay. Oslo: Tanum, 1968. Tilgjengelig på Nasjonalbiblioteket: https://www.nb.no/nbsok/nb/8580485394b3472f82c3d7be7afbd86a?index=1\#o

3. Tidsskrift for Den norske legeforening. «Ta vare på flokken din». https://tidsskriftet.no/2017/og/tavare-pa-flokken-din Lest 30.12.2021.

Publisert: 31. januar 2022. Tidsskr Nor Legeforen. DOI: 10.4045/tidsskr.22.0023

(C) Tidsskrift for Den norske legeforening 2023. Lastet ned fra tidsskriftet.no 26. april 2023. 